\title{
Albanian Legislative Review from Gender Equality Perspective - Achievements and Challenges
}

\author{
Elona Dini ${ }^{1}$ \\ ${ }^{1}$ Faculty of Social Sciences, University of Tirana, Albania \\ Correspondence: Elona Dini, Faculty of Social Sciences, University of Tirana, Albania.
}

Received: February 2, 2021

Accepted: February 23, 2021

Available online: February 23, 2021

doi:10.11114/ijsss.v9i2.5148

URL: https://doi.org/10.11114/ijsss.v9i2.5148

\begin{abstract}
Gender-based and domestic violence happens in all societies all over the world. During the last decade in Albania gender - based violence has become more visible as a major problem. Domestic violence has been considered as a private matter and not a society issue. Albania did not recognize existence of domestic violence until 2006, when it adopted the Law on Measures against Violence in Family Relations. Official data show an increase in the general prevalence of violence against women in the family, from 56\% in 2007 to $59.4 \%$ in 2013 and $52.9 \%$ in 2019. This legislative review presents an overview of the key legislative interventions in Albania to prevent gender-based and domestic violence and its impact in the society by highlighting main achievements and recommendations for further improvement, based on the analysis of results in the area. Methodology is based in a depth review of the key legal interventions on gender equality and domestic violence in the country. This review indicates that the response mechanisms have improved by following a multi-disciplinary point of view, however still profounder efforts are needed to provide proper services to domestic violence victims.
\end{abstract}

Keywords: gender, equality, legislation, violence, disaggregated data, interventions

\section{Introduction}

Albania is dedicated to respect and promote gender equality and gender-based violence. The country's achievement during the last years related to issues of gender equality and concretely in gender-based violence and domestic violence is underlines in a various number of international commitments on domestic legislation, development, and implementation of policies. Despite all the efforts to promote gender equality and fight gender based and domestic violence, progress is needed in many areas such as women participation in decision making process, women's representation in policy and development of policies and labor market (INSTAT, 2017).

Gender based and domestic violence against women is not a new phenomenon for the country of Albania. It is significant to emphasize that domestic violence seems to have origins in the cultural aspects of society. The origin of gender based and domestic violence lie in the entrenched patriarchal traditions and customs, norms and roles, adherence to an honor-and-dishonor system, and customs of male-controlled hierarchal ordering with the family, and all these has affected the role of women in the family and society for generations (INSTAT, 2018).

This paper aims to provide a clear review of the main legal interventions in the country to prevent gender based and domestic violence and give a view on the impact that it has in the society. The research is focused mainly on the albanian legislation, the adopted international legal frameworks by demonstrating how is gender equality and domestic violence positioned in the priorities of Albania.

The communist regime in Albania, even though it lasted for forty years during 1946 - 1991, it seemed to have not eliminated the cultural attitudes, norms and values that were deep in the patriarchal behaviors, including the laws known as Kanun of Lek Dukagjini which even nowadays are relevant in some remote areas of Albania. Men and women around the country seem to silently accept the canon law, thus explaining their views and attitudes related to gender roles and men's authority (Arsovska, 2007).

Since the fall of the communism in 1991, the Republic of Albania has ratified a series of important human rights conventions, including:

1. Accessed on 4 October 1991 the International Covenant on Civil and Political Rights, opened for signature 
19 December 1966, 999, UNTS 171 and 1057, UNTS 407 (entered into force 23 March 1976).

2. Ratified on 4 October 1991 the International Covenant on Economic, Social and Cultural Rights, opened for signature 19 December 1966, 993 UNTS 3 (entered into force 3 January 1976).

3. Ratified on 27 February 1992 the Convention on the Rights of the Child, opened for signature 20 November 1989, 1577 UNTS 3 (entered into force 2 September 1990).

4. Ratified on 10 February 1994 the European Convention for the Prevention of Torture and Inhuman or Degrading Treatment or Punishment, opened for signature 26 November 1987, 213 UNTS 22 (entered into force 1 February 1898).

5. Accessed on 11 May 1994 the Convention against Torture and Other Cruel, Inhuman or Degrading Treatment or Punishment, opened for signature 10 December 1984, 1465 UNTS 85 (entered into force 26 June 1987).

6. Accessed on 11 May 1994 the Convention on the Elimination of All Forms of Discrimination against Women, opened for signature 1 March 1980, 1249 UNTS 13 (entered into force 3 September 1981).

7. Ratified on 10 February 1996 the Convention for the Protection of Human Rights and Fundamental Freedoms, opened for signature 4 November 1950, 213 UNTS 221 (entered into force 3 September 1953).

8. Accessed on 1 August 2014 the Council of Europe Convention on preventing and combating violence against women and domestic violence, opened for signature 11 May 2011, 3011 UNTS (entered into force 1 August 2014).

From that time, international organizations and local non-governmental organizations have been working in collaboration with state institutions to deal with issues of gender equality and gender-based violence. Supporting efforts consist mainly in three intervention aspects: i) prevention like education and raising awareness campaigns, ii) protection related to the supporting and counseling services, sheltering; and iii) legal interventions that aim to protects victims of gender-based violence and better address domestic violence.

\section{Theoretical Framework}

Women's movements indicate the setting compared to which the concerns of gender inequality and inappropriate safety of the legislation for women and girls against violence will be measured. The progress of women's movements clearly marks and emphasizes how women are excluded and marginalized by limiting them and making harder their efforts to be equally represented in society and achieve gender equality (Bittman, 2001). Liberal feminism encourages women to compete with men related to economic and social payment via paid work. Eventhough, the liberal feminism points out the problem of women proper equality as per the law, it does not reflect concerns of social influence and the nonparticipation and representation of women in aspects of decision making, legal previsions and society in large. Thus, limiting the efficacy of legislation as a tool to develop progressively women's positioning in the society. On the other hand, the feminist legal theory aims to identify and fight the system made by men for men, leaving behind women and other vulnerable groups (Bowman, Schneider, 1998). Feminist critical theory provides opportunities for women to develop and progress themselves. All the above-mentioned theories related to women's movements address gender inequalities and show how laws affect women's rights by empowering them and making women included equally in all aspects of the society. Therefore, legal progress is key when comes to provision of equal rights, protection of women and girls and address areas that have real impact in their lives. In Albania, issues of gender-based violence have been taken into consideration through a series of interventions including legislation improvement, service provision and women participation in decision making. However, more efforts are needed to address specific issues that empower women and give them equal opportunities to have a say and be heard.

\section{Methodology}

The purpose of this review is focused on legislative achievements and challenges on gender perspective and concrete interventions related to gender quality and domestic violence. The article provides a comprehensive review of the legal instruments adopted and implemented in Albania about gender equality and the criminalization of domestic violence. A narrative review of literature was led to observe this research question: how has the legislative framework in Albania evolved in terms of gender equality and gender-based violence? Initial research related to the acceptance/ratification of the UN international treaties and their incorporation into national legislation for the protection of human rights, protection against gender-based violence and human is conducted. This is followed by a thorough revision of all the national legal changes and adoptions related to gender equality and domestic violence, such as laws, national strategies, Criminal Procedures Code and Family Code. A specific section is dedicated to national by laws as key in the provision of direct guides related to the implementation of the main laws line with international requirements. Official gazeetes, 
national reports and studies, articles are used as key source of information for the legislative review.

\section{Albania Legislative Interventions on Gender Equality Perspective}

During last 15 years Albania has achieved progress regarding the legislative framework in guarantying human rights and social protection for several groups focusing specifically on areas of gender equality and gender-based violence and domestic violence. The legal aspect on women's rights and domestic violence in Albania has enhanced through the ratification of a list of international instruments and a series of important amendments and adjustments to Albanian national legislation.

\subsection{Key Legislative Interventions and Improvements}

The Assembly of Albania adopted in 1998 the present Constitution of the Republic of Albania. The Constitution guaranties freedoms in the form of the fundamental rights, equality and respect for human dignity and nondiscrimination. More specifically the constitution states that: "Everyone is equal before the law and nobody can be discriminated on basis of gender, race, religion, ethnicity, language, and political, religious and philosophical stand, economic, educational and social status". Furthermore in relation to children rights and protection it sustains that: "Every child has the right to be protected from violence, maltreatment, exploitation and obligation for labor, especially under the minimal acquired age for labor, which can harm the health, moral or put the child's life or normal development at risk" (Constitution of the Republic of Albania, art. 18/2, art. 54/3, amend 2016 (ALB)).

Ministry of Labor, Social Affairs and Equal Opportunities to strengthen the rule of law on DV prepared the National Strategy on Gender Equality and Domestic Violence for 2007-2010, accompanied with a National Action Plan (NSGE-DV) (Official Gazette, no. 183 2007). This strategy aimed to achieve: i) gender equality through integrating and mainstreaming gender points of view into all aspects of policies developed and implemented; and ii) improve protection, performance of the judicial system, and provide services and support for gender based violence victims and work further to prevent the domestic violence origins.

For the period of 2011 - 2015 a second enhanced NSGE-DV and its implementation action plan was developed and approved (Official Gazette no.127 2011). The revised strategy brought specific attention on achievement of gender equality, reduction of gender-based and domestic violence. The strategy intended to address needs and rights of male and females and as well as vulnerable categories including women with disabilities, social class, ethnic background, and sexual orientation.

Meanwhile the latest developed national strategy on gender equality and action plan dated in 2016, represents a commitment for 2016-2020 with concrete interventions towards economic empowerment of women and men by: i) guaranteeing actual participation and involvement in decision-making processes at all levels; ii) decreasing violence in family realms and gender-based violence; and iii) consolidating the coordination and observation role of the national mechanism of gender equality (Council of Ministers Decision, No. 733, 2016 (ALB). This strategy has defined specific responsibilities and actions for the respective Ministries and other responsible institutions to be undertaken related to data collection and indicators for monitoring and evaluation process regarding to data collection. A novelty of this strategy is the annual data collection and inclusion of the percentage of prosecuted and rehabilitated perpetrators and the percentage of prosecuted and then rehabilitated perpetrators relative to total perpetrators.

Despite the government efforts working to improve not only the legislation, but also concrete interventions related to gender based violence issues, a group of international and local civil society organizations are working to approach issues of gender-based violence and they are urging for improved service support for victims of domestic violence. These civil society organizations are conducting awareness raising campaigns to increase awareness related to survivors of domestic violence and perpetrators. They are increasing capacity building for service providers such as victim advocates, legal and psychological counselors, medical staff, and law enforcement officers. The Law on Measures against Violence in Family Relations no. 96692006 (ALB) was adopted by the Assembly of Albania in 2016 and aims to prevent and decrease domestic violence of all forms by applying relevant legal measures, and to guarantee protection to family members, subject to domestic violence. Protection orders instituted by courts are stipulated in the law to provide protection measures against domestic violence. If a protection order is endorsed by police or prosecutor and if the victim want to drop the claim this will not affect the course of the judicial process. Worth to mention the fact that if the abused woman is the key testimony, the law defines the abused woman as a person that can claim no exception from testifying in a legal proceeding.

The legislative context in Albania has undergone through a series of key progresses by ratifying several important international instruments, amendments, and adjustments of the national laws related to gender-based violence, gender equality and human rights. The Law on Measures against Violence in Family Relations, no. 9669, 2006 amended as per law no. 47, 2018 (ALB) has undergone through several improvements and changes in 2008, 2010 and 2018. Aiming to 
better implement this law, a coordination mechanism for the treatment of domestic violence cases was introduced in 2011 (Council of Ministers Decision no. 334, 2011). Equality between women and men in all spheres of private and public life is further delineated in legislation such as in Law on Gender Equality in Society, no. 9970, 2008 (ALB). A set with harmonized indicators for gender equality and status of women in Albania was adopted in 2010 (Ministerial instruction No. 1220, 2010) accompanied by concrete steps on integrating gender aspects in the medium midterm budget programme (Council of Ministers Decision, no. 465, 2012). The Law on Protection against Discrimination no. 10221, 2010 (ALB) was accompanied with the creation of the Commissioner for the Protection against Discrimination as an independent institution aiming to preserve and protect human rights against discrimination.

Some relevant legislative amendments undertaken to support the above-mentioned laws are as follows:

1. Law on "Social Support and Services" no. 10 399, 2011 (ALB) that assures that the economic aid may be disbursed by the head of the household, but also from victims of domestic abuse, in case if a protection order is issued by the court in favor of the victim. As per this law, women may benefit to economic assistance even in the case if their husband is in a divorce process and there is not yet a final decision from the court.

2. Law on "Social Program for Housing in Urban Areas" no. 22, 2018 (ALB) treats the benefit of housing as a priority for divorced women dependent on children, women with disabilities, minors, orphan women and returning migrant women.

3. Law on "Legal Aid" no. 9355, 2013 (ALB) expanded the beneficiary categories of legal aid including: i) gender-based violence victims, human trafficking victims; ii) vulnerable people who register in social protection programs. The law during 2013 was subject to some improvements through offering legal aid from the budget of the state for those categories that i) justify the requirements to benefit from social protection scheme, and ii) are gender-based and domestic violence victims.

The newly approved Law on Free Legal Aid no. 111, 2017 (ALB) provides the establishment of a new department, within the Ministry of Justice, oversees a broadened set of primary and secondary free legal aid (FLA) providers, together with a new local office of the civil service and higher participation of NGOs service providers and the Bar membership. In this law as per article 11, among the categories of FLA direct beneficiaries, the following are identified: i) victims of domestic violence; ii) sexually abused victims and human victims trafficking, in every phase of a illegal proceeding; iii) minor victims and juveniles in conflict with the law, at any stage of a criminal proceeding; iv) children living in social care institutions; v) children with the custody who requires to proceed with no consent of the legal custodian or against the legal custodian; and vi) individuals that benefit from compensation for disability in as per the provisions of the law on social aid and services.

The Law on Anti-Discrimination No. 10221, 2010 (ALB) includes Sexual Orientation and Gender Identity (SOGI) by banning discrimination on these groups. Discrimination in during work, harassment and sexual harassment, offensive comments toward the employee related to SOGI are forbidden by the Labor Law. Administrative Procedures Code does not allow discrimination and obligation to proves passes to the suspected offender. The Law on Pre-University Education no.69 art.5 2012 (ALB) likewise does not allow discrimination towards SOGI. Free legal aid is provided to lesbian, gay, bisexual, transgender and intersex (LGBTI) individuals who are victims of domestic violence (UNDP 2017).

A progress was made towards the adjustments of the Criminal Procedures Code 79a, 113a, 121a, 130a 2017 (ALB) in relation to the protection of women and girls from domestic violence. To be mentioned are concrete improvements of this Code such as considering domestic violence an unlawful act, interposing stalking, prohibiting

Some of the specific measures undertaken during the amendments of this Code, included the need to make domestic violence a criminal offence, introduce stalking, criminalize involuntary sexual intercourse with adults, husband or partner without their will, banning sexual harassment or penalize the incentive, and prohibits payment for urging to prostitution.

A specific measure to be mentioned is under art.79a that expresses "murder effectuated under other eligible situations" consists of 2 groups i) juveniles; ii) disabled persons and persons with life threating health complications or pregnant individuals, as far as there is information for the victim's condition. The last amendments relate to the rights of sexually abused and victims of human trafficking, from which these victims can be listened immediately without postponement form a criminal police officer or prosecutor with the same gender.

The Family Code of Albania 2003 (ALB) consist of some articles related to domestic violence against husband/wife and child or children. The Family Code directs concretely parents' duties and children rights and child/children mistreatment. For example, art.62 states that "the abuser husband/wife may be removed from the marital home." Despite this, the above-mentioned article does not have other practical provisions. 


\subsection{National by Laws}

The Council of Minister's Order on the "Operation of the National Council on Gender Equality (NCGE) no. 3, 08.01.2009", in compliance of the Law no. 9970/2008 established the advisory body on gender equality composed of equal gender representation. Later NCGE has undergone changes in its composition. In 2017 the composition of NCGE was revised again, the number of deputy ministers increased to 10,3 civil society representatives were added, and the council would be chaired by Ministry of Health and Social Protection (Prime Minister's Order, No 239, 13.12.2017).

A specific focus has been made to implement improved legislative and policy framework on combating gender-based violence and in particular to build and strengthen coordinated community response which is transformed into national referral mechanism for managing the cases of domestic violence in compliance under the Law "On measures against violence in family relations" No. 96692006 and Council of Ministers Decision on the "Establishment of the national referral mechanism for the treatment of domestic violence cases and its way of functioning" No. 334, 2011 (ALB). The progress made in this aspect established the steering committee, for the coordination of activities of responsible bodies at local level and the referral of domestic violence cases, which every quarterly reports to the Ministry of Health and Social Protection on its activities, data and issues of domestic violence for the territory of its jurisdiction, by presenting such report and making real proposals for the support required by the central institutions. The representatives of other bodies at local level report every quarterly to their respective central institutions on their activities in the steering committee for the coordination of activities of responsible bodies, at local level and the referral of domestic violence cases.

In 2011 a series of Council of Minister's Orders were approved regarding establishment of services for victims of DV and GBV and standards for the following specific social services:

1. The Coordinated Referral Mechanism (CRM) of cases of domestic violence amended by Law No. 47/2018 on improvements and changes in Law on "Measures against violence in family relations" No. 9669, 2006 which means the organized network of responsible institutions at the local level for the prevention and protection, support and rehabilitation of victims of domestic violence.

2. The CRM constitutes the coordination mechanism composed by: a) steering committees for coordinating the activity of the authorities' institutions responsible, at the local level, and referring cases of domestic violence; b) interdisciplinary technical teams; c) local coordinators for referring cases of domestic violence and defines functions and responsibilities for each of them.

3. Establishment of the National Centre for Treatment of Victims of Domestic Violence, which was an important action of Albanian government in protection of GBV victims. This national shelter offers accommodation of women and children escorted by the Police accompanied with an immediate protection order or protection order issued by courts. (Council of Ministers Decision No. 36, 2011).

4. Decision on eligibility criteria and documentation required for admission of individuals in residential public and non-public social care institutions (Council of Ministers Decision No. 425, 27.06.2012) has defined in Chapter V the criteria for placements in residential centers where social care is provided, including victims of domestic violence and trafficking. Important changes in this chapter have occurred later regarding criteria for acceptance of victims and documentation to be completed by them for the placement in social care institutions.

5. Establishing the Standards for Social Care Services Provided to Domestic Violence Victims in Public and non-public Residential Centers (Council of Ministers Decision No. 505, 13.07.2011) which besides setting the standards for such services, has also defined the rules on the basis of which the shelters shall operate in their reception and accommodation of victims of domestic violence.

6. Standard Operation Procedures (SOPs) on Identification and Referral of Trafficking Victims or Possible Trafficking Victims (Council of Ministers Decision No. 582, dated 27.07.2011) regulate the identification and guideline actions, as well as the set of services for victims or potential trafficking victims.

7. Service standards for the victims of DV in the public and nonpublic residential centers include social care standards for victims of domestic violence who are accommodated in residential centers. Standards aim at improving the lives of victims of DV and their families, reflect the best practices in this area and the international principles of equality, etc. In addition to seven basic standards, the evaluation criteria, service quality measurement indicators, guidance and expected results are also included.

8. Standards for the services of national hotline consisted mostly to the provision of free national telephone line service for support, crisis counseling and referral of cases domestic violence and gender-based violence. Besides other standards it is defined the preservation of personal data of beneficiaries and their administration; monitoring and evaluation (UNDP Albania 2017). 


\section{Impact of the Implemented Laws}

\subsection{Domestic Violence and Related Laws Implementation}

An online tracking system of domestic violence cases (REVALB) was established in mid-2014 as an important cornerstone in monitoring and ensuring that pertinent legislation is implemented and that cases receive due inter-disciplinary attention. The establishment of the national electronic system to track domestic violence and also the building of capacities for local coordinators as civil servants to make use of the has increased institutions responsibilities and awareness to fulfill their duties and obligations related to sharing of information, reporting process and coordination between institutions. The online system registers the referral of domestic violence cases, guaranteeing that every registered case is managed and treated with the appropriate services. REVALB is complementary to the functioning of the CRMs aiming to prevent, report and effectively manage domestic violence cases. Council of Ministers Decision on the establishment of the national referral mechanism for the treatment of domestic violence cases and its way of functioning, No. 344, 2011 sets specific responsibilities for the relevant institutions in data collections, informing and recording via coordination and referral of domestic violence cases. The online system is secure, respects confidentiality and preserves privacy of victims of domestic violence. Local domestic violence coordinators and staff working at the Ministry of Health and Social Protections use the system and are continuously trained on how to use the system, register cases and generate reports on domestic violence data at local level. Since its establishment a total of 5.440 cases of domestic violence have been recorded in the system. From this data it is shown that women comprise most of domestic violence survivors and more than $22 \%$ of these are over 50 years old. About $73 \%$ of survivors live in the rural areas, while $34 \%$ are unemployed, $2 \%$ are survivors with disabilities and $98 \%$ of cases are immigrants (UNDP Albania, 2019).

The data provided by the system reveals that the higher referral and treatment of domestic violence cases is from the municipality directed to the other referral institutions members of the referral mechanism. This is noticed mainly in the municipalities of Elbasan, Korca, Pogradec Tirana, Puka, Vlora. Likewise, a high level of referral is also noticed by the police departments in Korca, Elbasan, Shkodra, Gjirokastra, Shkodra, the public health departments and local organizations specialized in providing services to domestic violence survivors.

Municipalities that are providing more support to domestic violence cases are municipalities of Korca, Puka, Tirana, Vlora, Lezha, Durres, Fier, Elbasan and Lushnje. A significant increase in the number of cases dealt with various support of services for domestic violence survivors is noticed in the largest municipalities of the country in Tirana, Korca and Vlora.

As stated in the latest GREVIO's Baseline Evaluation Report for Albania on legislative and other measures giving effect to the provisions of the Council of Europe Convention on Preventing and Combating Violence against Women and Domestic Violence in Albania, local referral mechanisms are the centerpiece of the country's coordinated multi-agency response to violence against women. The local referral mechanisms function at the municipality level and consists with several local institutions and local organizations offering services to domestic violence victims and aiming to create and provide coordinated response to domestic violence. Civil society organizations and international donors have been essential in creating the referral mechanisms that function in 29 municipalities out of the 61 in all the country (GREVIO 2017).

Other official data from Albanian State Police show the progress made during the last 13 years in implementation of the legislation in place on gender equality and domestic violence.

The number of reported cases on domestic violence has increased progressively with an average annual percent change by forty percent. A strong relationship exists between the reported cases to the police and the applied measures related to protected orders issued by the court where about sixty percent of reported cases have been accompanied by administrative and penal measures. There are also health related issues and severe physical consequences as a result of the domestic abuse, which leads to death. From the official data from the Albanian State Police in the number of fatal cases among DV victims fluctuate with up and downs in selected years but for the whole period the annual average percent change was decreasing with about three percent. It can be argued that with the approval of the Law on Measures Against Violence in Family Relations No.9696, 2006 (ALB) and enhanced awareness have led to higher reporting and better management of DV cases (Albanian State Police, 2019).

\subsection{Women in Politics and Decision Making}

The first data on the structure and composition of the Albanian Parliament derives since the legislation of 1920. In those years, the Albanian Parliament was composed by men only. The very first women member of the parliament was elected in the legislature of 1945. The participation rate of women members in Parliament has been increasing, with exception of years 1997, 2001 and 2005 that it had been less than ten percent. 
An important step has been also the Electoral Code legislative changes which had a direct impact in women participation in politics and decision making. A significant development in the number of women Members of Parliament (MPs) in Albania was possible upon the introduction of thirty percent quota in the amendments made to the Electoral Code, 2008 (ALB).

In the parliamentary elections of 2009, the participation of women in parliament more than doubled, from seven to sixteen percent. This progressive trend is also viewed in the parliamentary elections of year 2013, when it reached eighteen percent. In a three-year period, 2013 to 2016, the progressive increasing number of women and girls' members in parliament continues as an effect of the substitution of men member of parliament with women member of parliament due to the renunciation of men from their mandates. Due to this replacement, twenty nine percent of the Parliament in 2017 was comprised of women (INSTAT, 2018). Amid the parliamentary commissions in the assembly, the highest representation of women was in the Commission on Labor, Social Affairs and Healthcare, with around fifty percent. In this commission are discussed several laws and interventions that directly impact women and girl's life's related to empowerment and support to services (INSTAT 2017).

The adjustments and improvements made to the Electoral Code in 2015 were an important meaningful step towards women and girls' representation at decision-making in local level. These amendments allowed the lists of candidates to have ten percent women and ninety percent men in the local elections of 2015. These amendments to the Electoral Code significantly improve the gender representation after the democratic developments in Albania. In the local elections of 2016, the winning candidates for mayor were fifteen percent women and eighty five percent men. The participation of women and girls in municipal councils increased by threefold from twelve percent to thirty five percent and about thirty six percent of municipal councilors were women (INSTAT 2016).

Even though women's representation has constantly been increasing their role still needs to be further strengthened in order to reach equity among men not only on parliament but also at other levels of decision making at central and local level, having so the women voice heard, including here their needs and efforts not only to lead but also to have equal rights to men.

\subsection{Impact in Service Implementation Referring to Domestic Violence and Gender-Based Violence}

In Albania, there are six shelters for victims of domestic violence and gender-based violence. One of them is a national center and it is administered by the government and the others are run by NGOs. There are five emergency shelters situated in Shkodra and Elbasan, and three are emergency rooms in the municipalities of Pogradec, Permet and Saranda. Women's organizations that offer shelter for victims of domestic violence are accessible at any time and these shelters provide services for domestic violence survivors has around ninety-three beds for accommodation. The bed capacity in these shelters differs from five to fifty persons. However, this is far from what it is needed as Albania should provide 127 additional beds to meet the minimum requirement of the Council of Europe Convention 1 bed for 10,000 inhabitants (Council of Europe, UN Women 2015).

Shelters that are run by civil society organizations provide external support including counselling through telephone, advocacy, counseling of women that live out of the shelter, with the exclusion of the first national shelter for abused women and girls run and administered by the government. But it is to be mentioned the fact that the shelters locations are not public due to security, safety, and privacy aspects and this makes difficult for victims of domestic abuse to access them easily. To have access to these shelters' services the victims, women or girls must go through a series of procedures to enter and be accommodated in a shelter. Accommodation in shelters differs from one shelter to another, varying in the type of services offered. For instance, the allowed stay in the emergency shelters in not more that a week, meanwhile in the national shelter the accommodation period is seven to twelve months. (UNDP Albania 2018). However, government at central and local level, has been doing many efforts in establishing and making functional other emergency shelters to provide support to victims of domestic violence and other forms of violence, specifically sexual violence victims. Under the custody of the Ministry of Health and Social protection, in 2019 became functional the first center providing emergency services to sexual violence victims. During the first year of operation the center has managed to offer tailored services to 37 victims of sexual violence (UN Women 2019).

Even though the many efforts to provide the appropriate services to victims of domestic violence the report of the implementation of the Convention on the Elimination of all Forms of Discrimination Against Women (CEDAW) underlines that unless progress is made, the absence of services for victims at the local level remains an issue to be addressed despite the positive model and the cooperation of the government and shelters managed by civil society organizations, provision of supporting services for women survivors of domestic violence is not equal and not accessible by all groups in need of services. For example, women and girls in rural area lack more and are limited to support services related to domestic violence. (CEDAW Report 2016). This underlines the need to increase concrete service provisions for victims of domestic violence to achieve the required standards by national and international laws in Albania. 


\section{Discussion}

There is a notable progress in the impact that has the Criminal Procedures Code 2017 (ALB) and its amendments on the data collected by Ministry of Interior and State Police. A novelty to these amendments is the specification of vulnerable categories subject to domestic abuse, more concretely as stated below murder committed under other qualifying circumstances, that include two new categories firstly juveniles and persons with disabilities, persons with diseased threating their lived or pregnant women/girls, so far as there is concrete information on the situation of the victim [Criminal Procedures Code 2017, 79a (ALB)]. Further efforts towards a stronger and systematic system to monitor various governmental institutions related to the law implementation and increase their responsibilities and accountabilities would improve the effectiveness of policies implementation and service provision.

Prime Minister's Orders are approved regarding establishment of services for victims of domestic abuse and gender-based violence. These standards guarantee preservation of personal data of beneficiaries and their administration and developing of monitoring and evaluation systems, which include data collection as well. Even though the improvements and efforts are made to provide services to victims of gender based and domestic violence, a better development cooperation between central and local government in terms of policies implementation and management of resources, specifically when it comes to the provision of services for domestic violence cases would be necessary. A more efficient cooperation with district courts, police stations, prosecution, free legal services, social services, shelters, health care clinics and civil societies organizations will help to a better management of domestic violence cases as well as shorten the response time by state and non-state services to domestic violence survivors. An increased cooperation would improve the effectiveness of the referral mechanism of domestic violence, as a result reduction of the management cost of domestic violence cases. Continuous training and capacity building of government employees would be a necessity on the implementation of the legislation in place regarding gender-based violence and domestic violence to increase effectiveness and improve impact of providing services.

Resolution for penalty of violence against women and increasing effectiveness of its legal prevention mechanism adopted on 2017 has underlined the need for data on employment of women and girls, victims of domestic violence that should be collected by all the institutions, public and private sectors to be part of the periodic reports deposited in the Assembly of the Republic of Albania. Having this said, significant progress is made in creating a collecting data system related with the establishment of national electronic register REVALB, a standardized online system of recording domestic violence cases, referrals and institutional support given to victims. The establishment of this system comes as complementary to the National Coordination Referral Mechanism of Domestic Violence Cases (Council of Ministers Decision no.334 2011). All these are great efforts made toward fighting violence and gender based violence in the country, showing the commitment of the government at central and local level but also the cooperation and the need to gather forces with civil society organizations combining professional capacities and services to manage and reintegrate victims of gender-based violence.

\section{References}

Arsovska, J. (2007). Social Confusion on the Road to Modernity: The Meaning of Violence and Crime in Ethnic Albanian Context. Final Report. Prague, Czech Republic: CERGE-EI GDN Project. Retrieved from https://www.cerge-ei.cz/pdf/gdn/rrc/RRCVI_54_paper_01.pdf

Assembly of the Republic of Albania. (2017). Resolution On combating violence against women and girls and increasing the effectiveness of legal mechanisms for its prevention. Retrieved from http://www.parlament.al/Files/Projekte/vendim-nr-113-dt-4-12-2017-1.pdf

Bimbashi, E. (2017). Baseline report SDG 16 indicators 16.1 and 16.2. Albania. UNDP Albania. https://doi.org/10.5089/9781484379097.002

Bimbashi, E., \& Kalaja, D. (2017). Standards for the services of the national hotline. Albania. UNDP. Retrieved from Available:https://www.al.undp.org/content/albania/en/home/library/poverty/standartet-e-sherbimit-te-linjes-kombet are-te-keshillimit-per-vi0.html

Bittman, M. (2001). Family and Gender. International Encyclopedia of the Social and Behavioral Sciences, 5286-5290. https://doi.org/10.1016/B0-08-043076-7/03942-5

Bowman, C., \& Schneider, E. (1998). Feminist Legal Theory, Feminist Lawmaking, and the Legal Profession, 67 Fordham L. Rev. 249. Retrieved from https://ir.lawnet.fordham.edu/flr/vol67/iss2/2

Convention against Torture and Other Cruel, Inhuman or Degrading Treatment or Punishment, 26 June 1987. Retrieved from https://treaties.un.org/pages/ViewDetails.aspx?src=IND\&mtdsg_no=IV-9\&chapter=4\&clang=_en

Convention for the Protection of Human Rights and Fundamental Freedoms, 3 September 1953. Retrieved from https://treaties.un.org/Pages/showDetails.aspx?objid=080000028014a40b 
Convention on the Elimination of All Forms of Discrimination against Women, 3 September 1981. Retrieved from https://treaties.un.org/Pages/ViewDetails.aspx?src=IND\&mtdsg_no=IV-8\&chapter=4\&lang=en

Convention on the Rights of the Child, 2 September 1990. Retrieved from https://treaties.un.org/pages/ViewDetails.aspx?src=IND\&mtdsg_no=IV-11\&chapter=4\&lang=en

Council of Europe Convention on preventing and combating violence against women and domestic violence, 1 August 2014. Retrieved from https://treaties.un.org/Pages/showDetails.aspx?objid=08000002804031c8\&clang=_en

Council of Europe, UN Women (2015). Albania-Mapping of Support Services against Violence against Women and Girls'.

Council of Ministers Decision on "Establishment of the National Centre for Treatment of Victims of Domestic Violence" No. 36, 2011. Retrieved from https://evaw-global-database.unwomen.org/en/countries/europe/albania/2011/prime-ministers-order-no-36

Council of Ministers Decision on "Standard Operation procedure (SOPs) for the Identification and Referral of Victims or Potential Victims of Trafficking" No. 582, dated 27.07.2011. Retrieved from https://childhub.org/en/system/tdf/library/attachments/psv_2018_en_cover_0.pdf?file=1\&type=node\&id=39587

Council of Ministers Decision, No. 733, 20.12.2016 on the "National Strategy of Gender Equality and its accompanying action plan". Retrieved from https://www.un.org.al/sites/default/files/SKGJB-AL-web.pdf

European Convention for the Prevention of Torture and Inhuman or Degrading Treatment or Punishment, 1 February 1898. Retrieved from https://www.coe.int/en/web/conventions/full-list/-/conventions/treaty/126

INSTAT (2016). Women and Men in Albania. Tirana - Albania: Institute of Statistics. Retrieved from http://www.instat.gov.al/en/publications/books/2016/women-and-men-in-albania-2016/

INSTAT (2017). Women and Men in Albania. Tirana - Albania: Institute of Statistics. Retrieved from http://www.instat.gov.al/media/1143/burrat_dhe_grat_ne_shqiperi_2017_libri.pdf

INSTAT (2018). Violence Against Women and Girls in Albania. Tirana - Albania: Institute of Statistics. Retrieved from https://www.undp.org/content/dam/albania/NewPublications/VAW\%20Survey\%202018.pdf

International Covenant on Civil and Political Rights, 23 March 1976. Retrieved from https://treaties.un.org/pages/ViewDetails.aspx?src=TREATY\&mtdsg_no=IV-4\&chapter=4\&clang=_en

International Covenant on Economic, Social and Cultural Rights, 3 January 1976. Retrieved from https://www.ohchr.org/en/professionalinterest/pages/cescr.aspx

Kumwenda R, (2017). Being LGBTI in Eastern Europe: Albania Country Report, Reducing Inequalities \& Exclusion and Combating Homophobia \& Transphobia experienced by LGBTI people in Albania. UNDP. Retrieved from http://www.al.undp.org/content/dam/albania/docs/ALBANIA\%20FINAL\%20REPORT\%2018.10.2017.pdf

Law No. 47/2018 on amendments and changes in Law on "Measures against violence in family relations" No. 9669, 2006. Retrieved from http://www.parlament.al/Files/Akte/ligj\%20nr.\%2047,\%20dt.\%2023.7.2018.pdf

Law No.10 399, 17.3.2011 on some amendments on Law Nr. 9355,10.03.2005," On Social Assistance and Services”, art.5/5. Retrieved from https://www.ilo.org/dyn/natlex/docs/ELECTRONIC/94174/110431/F633707118/ALB-94174.pdf

Law on Albanian Electoral Code, No. 10 019, 2008. Retrieved from http://www.pp.gov.al/web/kodi_zgjedhor_24.pdf

Law on Criminal Procedure Code of the Republic of Albania No.7905, date 21.3.1995. Amended by Law no.145/2013. Amended by Law no.35/2017. Retrieved from https://www.legislationline.org/download/id/8236/file/Albania_CPC_1995_am2017_en.pdf

Law on the Albanian Electoral Code, No. 10 019, 2008, amended by Law No. 74, 2012 and Law No. 31, 2015. Retrieved from http://cec.org.al/wp-content/uploads/2017/06/KODI-ZGJEDHOR-2015-Teksti.pdf

Literary Theory and Schools of Criticism". Purdue OWL. Retrieved from https://owl.purdue.edu/owl/subject_specific_writing/writing_in_literature/literary_theory_and_schools_of_criticis $\mathrm{m} /$ feminist_criticism.html

Official Gazette No 241, 31/12/2017, Law No. 111, 14/12.2017 on "Free legal aid guaranteed by government" p.13351. Retrieved from https://qbz.gov.al/eli/fz/2017/241/039b444c-dc1f-4f42-9bee-ff2e4942a606;q=ligji\%20per\%20ndihmen\%20juridike $\% 20$ falas

Official Gazette No. 111, 30.08.2012, Council of Ministers Decision No. 465, 16.07.2012 on "Gender mainstreaming in the medium midterm budget programme" p.6485. Retrieved from 
https://qbz.gov.al/eli/fz/2012/111/7ecf29c8-ac21-4bcf-a1f6-fe19d04f729c;q=VKM\%20465\%202012\%20\%20buxh etimi\%20gjinor

Official Gazette No. 125, 01.08.2009 on the Law No. 9970, 24.07.2008 on "Gender Equality in Society" p. 5540. Retrieved from https://qbz.gov.al/eli/fz/2008/125/38d37ac3-b250-40f0-bc61-0fe49024533e;q=ligji\%20per\%20barazine\%20gjinor e\%202008

Official Gazette No. 142, 25.10.2010 on some addenda to Law No. 9669, 18.12.2006 on "Measures against violence in family relations" p. 7703. Retrieved from https://qbz.gov.al/eli/fz/2010/142/b83958e2-005b-4683-955a-c327424e4a9d;q=142

Official Gazette No. 15, 2010, Law No. 10221, 04.02.2010 on "Protection against discrimination" p.482. Retrieved from https://qbz.gov.al/eli/fz/2010/15/e954b332-0d78-48cf-936d-bcac381b7d55;q=ligji\%20per\%20mbrojtjen\%20nga\% 20diskriminimi $\% 202010$

Official Gazette No. 150, 31.12.2006, Law No. 9669, 18.12.2006 "On Measures against Violence in Family Relations" Retrieved from https://qbz.gov.al/eli/ligj/2006/12/18/9669/3257bc3f-964e-4d84-aca0-57122d81f986

Official Gazette No. 75, 13.06.2011, Council of Ministers Decision No. 334, 17.02.2011 on the "Establishment of the national referral mechanism for the treatment of domestic violence cases and its way of functioning" p. 3031. Retrieved from https://qbz.gov.al/eli/fz/2011/75/83d0a9d3-f1fb-4779-bb19-467660ee28f9;q=VKM\%20334\%20per\%20mekanizmi $\mathrm{n} \% 20 \mathrm{e} \% 20$ rferimit

Official Gazette No.78, 02.07.2010, Instruction No. 1220, 27.05.2010 on the "Harmonized indicators for gender equality and status of women in Albania" p. 4071. Retrieved from https://qbz.gov.al/eli/fz/2010/78/c6f60987-5962-4eb5-a09a-40ae3e8859a7;q=treguesit\%20e\%20harmonizuar\%20b arazia\%20gjinore\%202010

Official Gazette, No. 127, 07.09.2011, Council of Ministers Decision No. 573, 16.06.2011 on the "Approval of the national strategy for gender equality and reduction of gender-based violence in family for 2011-2015 and its accompanying action plan", p. 5651. Retrieved from

https://qbz.gov.al/eli/fz/2011/127/bc518a8b-7508-432e-89c3-1e375707b495;q=ligji\%20per\%20barazine\%20gjinor e\%202008

Official Gazette, No. 183, 19.12.2007, Council of Ministers Decision No. 913, 19.12.2007 on the "Approval of the national strategy for gender equality and domestic violence 2011-2015 and its accompanying action plan", p. 5689. Retrieved from

https://qbz.gov.al/eli/fz/2007/183/75e95499-36f9-4929-baf8-459e5ebb6e5d;q=strategjia\%20kombetare\%20per\%2 Obarazine\%20gjinore\%202007

Prime Minister's Order, on "Establishment of the National Council of Gender Equality” No 239, 13.12.2017. Retrieved from https://new.shendetesia.gov.al/wp-content/uploads/2018/03/NJOFTIM._WEB_KKBGJdocx.docx

The Constitution of the Republic of Albania 2016 (ALB), art. 18/2, 16; art. 54/3, 26. Retrieved from http://www.pp.gov.al/web/kushtetuta_2016_1082.pdf

The Group of Experts on Action against Violence against Women and Domestic Violence (GREVIO). Evaluation Report on legislative and other measures giving effect to the provisions of the Council of Europe Convention on Preventing and Combating Violence against Women and Domestic Violence (Istanbul Convention), Albania. 24 November 2017, p.9. Retrieved from https://rm.coe.int/grevio-first-baseline-report-on-albania/16807688a7

UN Women, (2016). Report on the implementation of the Convention on the Elimination of all Forms of Discrimination Against Women (CEDAW) in Albania. Retrieved from https://un.org.al/sites/default/files/CEDAW-Avokati-EN.PDF

UN Women, (2019). Generation Equality in Albania stands against rape. Retrieved from https://albania.unwomen.org/en/news-and-events/stories/2019/12/generation-equality-in-albania-stands-against-rap e

\section{Copyrights}

Copyright for this article is retained by the author(s), with first publication rights granted to the journal.

This is an open-access article distributed under the terms and conditions of the Creative Commons Attribution license which permits unrestricted use, distribution, and reproduction in any medium, provided the original work is properly cited. 